\title{
Cosimo I and the Joseph Tapestries for the Palazzo Vecchio
}

\author{
GRAHAM SMITH
}

In mid May, 1540, more than three years after he was named capo of Florence and more than a year after he was declared Duke, Cosimo I de' Medici (Fig. 1) moved with his wife and infant daughter from the Palazzo Medici on the Via Larga to the Palazzo dei Priori on the Piazza della Signoria. Cosimo himself referred to the event in a letter to his father-in-law, Pedro de Toledo, the Imperial Governor of Naples. After assuring Pedro that his daughter Eleonora was happy and in the best of health, Cosimo continued, "Et ella et io oggi col nome del N. ${ }^{\text {tro }} \mathrm{S}$. ${ }^{\text {re }}$ Idio siamo entrati in possessione del palazzo maggiore dove sono stanze regali. Piaccia a S. Maestà divina che sia in buon punto, con salute e accrescimento delle persone nostre e de' figliuoli e con pace et tranquillità de' sudditi di questo dominio.",1

In addition to transforming the former Palazzo del Popolo into a Palazzo Ducale, the Medici change of residence generated an extensive programme of modernization and decoration, which continued until Cosimo's death in 1574. One of the most important undertakings of the first phase of this programme was the production of a series of twenty tapestries in wool, silk, silver and gold for the Salone dei Duecento on the second floor of the palace, one of the "stanze regali" mentioned by Cosimo in his letter and by far the grandest room in his own quarters. Based on designs by Bronzino, Pontormo and Salviati, and woven by the Netherlanders Janni Rost and Nicholas Karcher, the tapestries illustrate the life of Joseph. At least one tapestry was on the looms by October 1546; ten tapestries had been delivered by August 1549; and all twenty tapestries were recorded in an inventory of the ducal wardrobe made in 1553. The series is now divided between the Soprintendenza in Florence and the Palazzo del Quirinale in Rome. The Joseph tapestries have been discussed in considerable detail since their rediscovery in the nineteenth century. However, scholars have focused upon questions of documentation, attribution, chronology and arrangement, in addition to discussing broader matters of style, composi- 
184 / Renaissance and Reformation

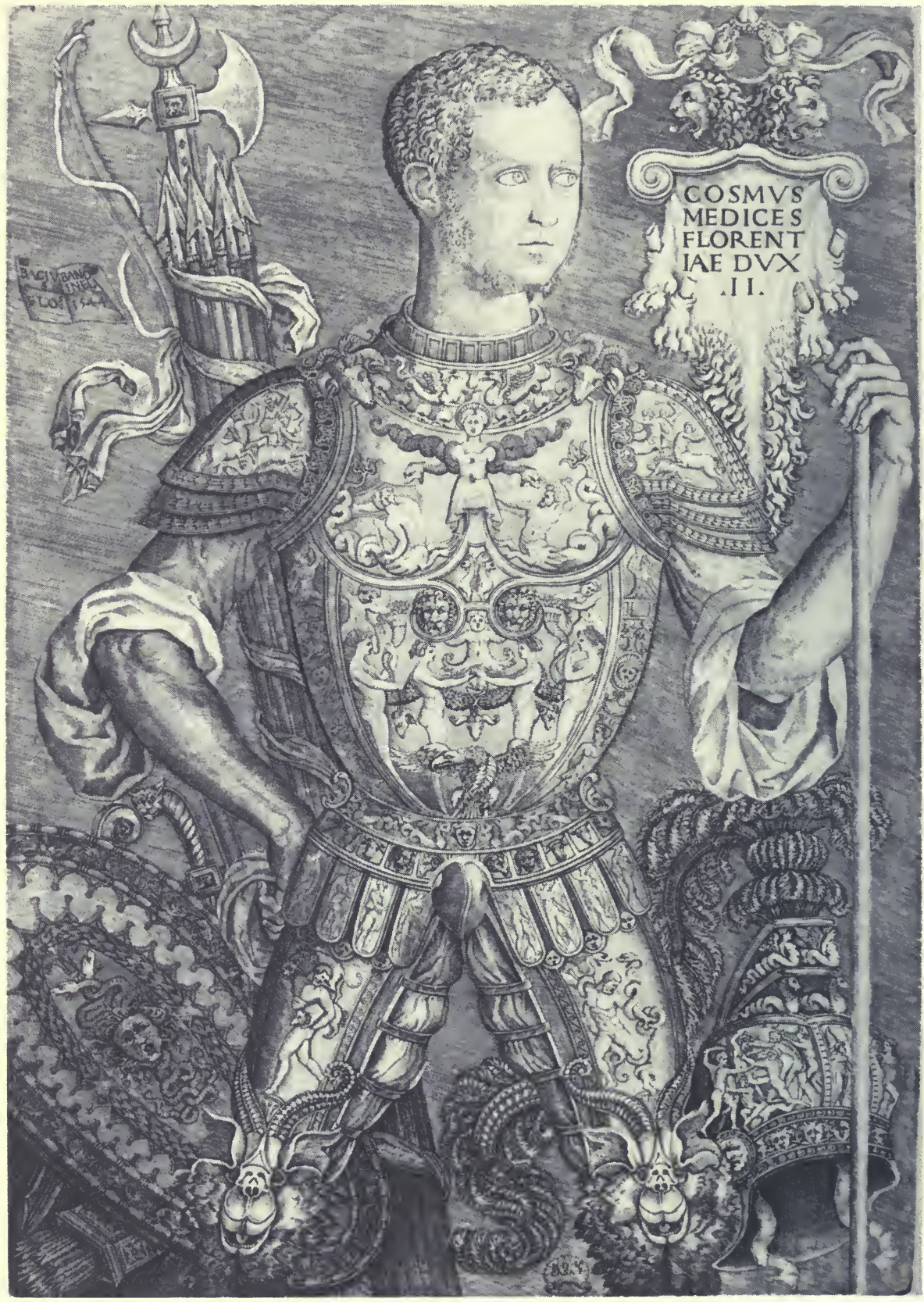

Niccold della Casa, Portrait of Cosimo I de' Medici, engraving after Baccio Bandinelli. Minneapolis, The Minneapolis Institute of Arts. 
tion and preparatory studies. Consequently, very little attention has been given to the subject matter and programmatic significance of the cycle. ${ }^{2}$

As it is told in Genesis 37-50, the story of Joseph unfolds in three parts or acts: the first deals with Joseph's childhood; the second recounts his tribulations in Egypt; and the third commemorates his elevation and ministry as Pharaoh's viceroy. Cosimo I's tapestry cycle for the Salone dei Duecento treats all three periods in the career of Joseph, but it does so with unequal emphasis. Four of the tapestries illustrate the childhood - the Dream of the Sheaves of Corn, Joseph Interpreting the Dream of the Sun, Moon and Stars (Fig. 2), the Sale of Joseph and the Lament of Jacob (Pontormo). Similarly, four tapestries are devoted to the period of trials in Egypt - the Temptation of Joseph or Joseph Accused by Potiphar's Wife, Joseph Fleeing from the Wife of Potiphar (Fig. 3), Joseph in Prison and the Banquet of Pharaoh and Joseph Interprets Pharaoh's Dream of the Fat and Lean Kine (Salviati). In contrast, twelve tapestries commemorate Joseph's ministry in Egypt - the Distribution of Grain to Joseph's Brothers, the Taking of Simeon, Joseph Receiving Benjamin, Joseph Entertains his Brethren, the Discovery of Joseph's Cup in the Sack of Benjamin, Joseph Takes Benjamin as his Servant and Judah Begs for the Release of Benjamin (Pontormo), Joseph Reveals Himself to his Brethren, Joseph Pardons his Brethren, the Reunion of Joseph and Jacob in Egypt, Pharaoh Presents the Land of Goshen to Jacob and his Family, Jacob Blesses the Sons of Joseph and the Burial of the Bones of Joseph (Joshua 24:32). Even from this list of titles it is evident that Cosimo I's tapestry cycle focuses upon the triumph of Joseph in Egypt and especially upon his renewed dealings with his family, culminating in their resettlement in Egypt. ${ }^{3}$

Two major Florentine Joseph cycles must have stimulated Bronzino, Pontormo and Salviati in some fashion when they began to prepare designs for Cosimo I: the earlier cycle is the late thirteenth-century mosaic series of fifteen scenes in the cupola of the Baptistery; ${ }^{4}$ closer in time to the tapestries are the panels by Andrea del Sarto, Pontormo, Granacci and Bacchiacca, which Salvi Borgherini commissioned in honour of the marriage of his son, Pierfrancesco, to Margherita Accaiuoli in $1515 .^{5}$

The Borgherini cycle was made up of fourteen paintings which are now distributed among collections in Florence, Rome and London. The cycle began with a complex panel by Andrea del Sarto illustrating seven episodes from the childhood of Joseph, beginning with Joseph's dreams and ending with the lament of Jacob. The scenes represented by the first four tapestries all appear in Sarto's painting. Four pictures were devoted to the period of trials in Egypt in the Borgherini series - Joseph Sold to Potiphar, by Pontormo, Joseph Taken to Prison, by Granacci, the Banquet of Pharaoh, by Pontormo, and the Interpretation of the Dreams of Pharaoh, by Andrea del Sarto. In this group only two of the paintings 
have counterparts among the tapestries. Also, the erotic episode involving Joseph and Potiphar's wife, which is given considerable prominence in the tapestry cycle, is glossed over in Granacci's picture, which concentrates instead upon Joseph's punishment. The remaining nine paintings illustrate Joseph's ministry in Egypt and the story of his renewed association with his family. This group began with the Distribution of Grain to Joseph's Brothers and the Arrest of Simeon, by Pontormo, and continued with two small pictures by Bacchiacca, also illustrating episodes connected with the arrest of Simeon. It continued with four more paintings by Bacchiacca, representing scenes from Joseph's step-brothers' second trip to Egypt - Joseph Receiving Benjamin, the Search for Joseph's Cup, the Discovery of Joseph's Cup in the Sack of Benjamin and Joseph Takes Benjamin as his Servant and Judah Begs for the Release of Benjamin. The last two paintings are Joseph Introducing Five of his Brethren to Pharaoh, by Granacci, and Joseph Introduces Jacob to Pharaoh and Jacob Blesses the Sons of Joseph, by Pontormo. Up to the panel representing Joseph Taking Benjamin as his Servant the subject matter of the Borgherini paintings in the third group agrees with that of the tapestry cycle. However, the last tapestries illustrate four episodes that are not represented specifically in the paintings - Joseph Reveals Himself to his Brethren, Joseph Pardons his Brethren, the Reunion of Joseph and Jacob in Egypt and the Burial of the Bones of Joseph. ${ }^{6}$

Despite parallels in subject matter and occasional relationships in composition between the Borgherini paintings and the Joseph tapestries, the Borgherini series is not entirely satisfactory as a model for the tapestry cycle. In the tradition of cassoni, the Borgherini pictures are relatively small in scale and intentionally intimate in nature. In contrast, the tapestries for the Salone dei Duecento compare in scale with almost exactly contemporary monumental Roman decorations, such as Perino del Vaga's Sala Paolina in Castel Sant'Angelo or Vasari's Salone dei Cento Giorni in the Palazzo della Cancelleria. Moreover, in size, splendour and extravagance Cosimo's tapestry certainly was intended to bring to mind first Raphael's great series for the Sistine Chapel. ${ }^{7}$

As a major public decoration, the mosaic cycle in the cupola of the Baptistery of Florence perhaps provides a better model for the manner in which the tapestries were intended to function than do the Borgherini panels. Moreover, in terms of subject matter the mosaics do offer a rather precise model for the selection of scenes from the youth and trials of Joseph found in the tapestries. In fact, with only two exceptions, the mosaics and the tapestries parallel each other scene by scene, beginning with the dreams of Joseph, continuing with Joseph's sale into Egypt, and concluding with his interpretation of the dreams of the butler and baker and those of Pharaoh himself. The points at which the cycles deviate are 
as follows: the mosaic cycle includes Potiphar's purchase of Joseph, but omits the attempted seduction of Joseph by Potiphar's wife; and Pharaoh's investiture of Joseph is represented in the Baptistery but not in the tapestries.

Despite the general correspondence between the mosaic cycle and the tapestry series, there are also significant differences between the two. Most important, in the Baptistery the triumph of Joseph appears only as an abbreviated postscript to the childhood and trials, a mere three scenes being devoted to it. Those are Joseph Directing the Storage of Grain, a scene absent from the tapestry cycle, Joseph's Reconciliation with his Brothers and Joseph's Reunion with Jacob. ${ }^{8}$

On the basis of the material discussed so far, it is possible to make two general observations on the nature of Cosimo I's tapestry series. The first is that the tapestries constitute an unusually elaborate Joseph series, even when compared with a late medieval narrative cycle such as that in the Baptistery. The second is that Cosimo's cycle, like the Borgherini series, places considerable emphasis upon Joseph's elevation in Egypt and, in particular, on his renewed relations with his family.

From the beginning of his rule, Cosimo I de' Medici developed an elaborate personal imagery through which he associated himself with historical figures such as Augustus and Alexander, mythological heroes such as Hercules, and old testament personalities such as Moses, Solomon and David. ${ }^{9}$ In the tapestry series Cosimo presumably intended to present himself as a new Joseph, just as in other contexts he had hoped to be accepted as another Augustus or a modern Hercules. However, although the relationships between Cosimo and Augustus or Hercules and certain other antetypes have been developed in considerable detail by modern scholars, the appropriateness of pairing Cosimo with Joseph has not been explored. The remainder of this paper will consider reasons for Cosimo I's selection of Joseph as the subject of his tapestry series, and will attempt to explain the particular emphasis of the cycle.

Although the commercial and mercantile aspects of the Joseph story had seemed appropriate to a banking family such as the Borgherini - or to the earlier Medici for that matter - they could hardly have constituted the principal reason for Cosimo's selection of the subject for his tapestry cycle. Similarly, the allusions to matrimony and clothing, mentioned by Braham, ${ }^{10}$ while appropriate in the case of the Borgherini cycle, given its function as part of the furnishings of a nuptial chamber, are hardly relevant to the tapestry series. On the other hand, the dynastic aspect of the Joseph story, also mentioned by Braham in connection with the Borgherini decorations, certainly had appealed to Cosimo, as will be discussed below.

The most usual and also the richest interpretation of the Joseph story 
was of course the Christian one, according to which Joseph was a typus Christi whose life prefigured that of Christ in all its details. ${ }^{11}$ However, this parallel does not seem directly relevant to the tapestry series, given its secular context. Perhaps more immediately applicable is the view of Joseph as the ideal bishop, combining religious and moral virtues with civil and administrative abilities. This interpretation of Joseph, which can be traced back to St. Ambrose among others, is familiar from Meyer Schapiro's classic study of the throne of Maximianus at Ravenna. ${ }^{12}$ Less well-known, however, is Schapiro's suggestion that this more worldly exegesis of the life of Joseph may have been inspired by a treatise written by the first-century theologian and philosopher, Philo Judaeus. In fact, Philo's treatise on Joseph - which has the subtitle The Life of the Statesman - offers a plausible explanation for Cosimo de' Medici's adoption of the old testament figure. ${ }^{13}$

The writings of Philo Judaeus were in fact collected and studied extensively during the fifteenth and sixteenth centuries. For example, early in the fifteenth century Niccolò Niccoli acquired an important fourteenthcentury Philo codex containing the life of Moses, the treatise on Joseph and other works. Later Niccoli's codex passed to the library of the Convent of S. Marco, and it is now in the Biblioteca Laurenziana in Florence. ${ }^{14}$ In the late fifteenth century in Rome, Lilius Tifernas translated the complete works of Philo for Sixtus IV, and it is likely that Philo's life of Moses had a role in the elaboration of the fifteenthcentury fresco programme in the Sistine Chapel. ${ }^{15}$ Moreover, references to Philo are scattered among the writings of Roman and Florentine humanists, such as Francesco Filelfo and Angelo Poliziano. ${ }^{16}$ This being the case, it is entirely likely that Philo's writings had been brought to the attention of Cosimo I. Finally, it is of some significance that an Italian version of Philo's treatise on Joseph was published in Venice in 1574, the year of Cosimo's death, with the title Il ritratto del vero e perfetto gentiluomo. Although this publication post-dates the first tapestries by almost thirty years, its very existence perhaps lends support to the idea that the Joseph tapestries could have been understood in terms of Philo's thinking by the contemporaries of Cosimo I.

According to Philo Judaeus, Joseph's upbringing and his trials in Egypt constituted the perfect preparation for his subsequent career as the viceroy of Pharaoh. Joseph's training as a shepherd gave him practice in the "exercise of authority," since "the shepherd's craft . . . corresponds closely to the lore of statesmanship" (p. 141). Similarly, Joseph's supervision of the household of Potiphar gave him valuable administrative experience, "for a house is a city compressed into small dimensions, and household management may be called a kind of state management, just as a city too is a great house and statesmanship the household management of the general public"' (p. 161). 
At a less literal level, Philo maintained that aspects of Joseph's life should be considered as allegories of the life of the statesman. According to Philo, life is a dream, "full of ... vast confusion and disorder and uncertainty," and the responsibility of the statesman is, "like some wise expounder of dreams, [to] interpret the day-time visions and phantoms of those who think themselves awake, and with suggestions commended by reason and probability shew them the truth about each of these visions" (p. 209). In his capacity as interpreter of the various dreams of the butler, baker and Pharaoh, Joseph then is acting as a model statesman, indicating "what is prudent, courageous, pious, religious, beneficial, profitable, and conversely what is unprofitable, unreasonable, ignoble, impious, irreligious, deleterious, harmful, selfish" (p. 209). A second example of Philo's allegorical interpretation of the career of Joseph occurs in relation to the escapade with the wife of Potiphar. According to Philo, Potiphar's lustful wife symbolises the people, since "like a licentious woman the desire of the multitudes makes love to the statesman" (p. 173), and Joseph's stout resistance demonstrates his possession of the statesman's virtue of selfcontrol (p. 171).

After praising Joseph's "comeliness, wisdom and power of language," Philo concluded his Life of the Statesman by recording that Joseph was "a most admirable supervisor and arbiter in times both of famine and plenty, and [was] most capable of presiding over the requirements of both" (p. 271). Cosimo I de' Medici also proved himself to be "a most admirable supervisor and arbiter" as Duke of Florence, and he too was adept at interpreting the "day-time visions and phantoms" of his people. This being the case, it seems quite reasonable to believe that Cosimo, like Philo Judaeus, may have interpreted Joseph as the ideal statesman and perhaps also as a mirror of Cosimo himself.

There are in fact various circumstantial relationships between the lives of Joseph and Cosimo, and those may well have suggested a more elaborate paralleling of the two rulers. Joseph, like Cosimo, was a member of a junior branch of his family; secondly, Joseph's miraculous rise to the position of viceroy to Pharaoh prefigures rather nicely Cosimo's own meteoric rise to the position of capo and then Duke of Florence; and finally, Joseph's triumph over exile may have suggested comparisons with the Medici family's various returns to power in the city of Florence. ${ }^{17}$ However, more immediately relevant to the idea that Philo's treatise on Joseph may have contributed to the development of the iconographic programme of the tapestry cycle is the fact that the virtues of self-control, prudence and magnanimity, attributed to Joseph by Philo Judaeus, appear to have been especially cultivated by Cosimo.

Remarkably straitlaced, Cosimo I was famous for his chastity and marital fidelity. ${ }^{18}$ Moreover, as a reaction against the extreme licentiousness of Alessandro's rule, Cosimo framed new sumptuary laws and enforced 
190 / Renaissance and Reformation

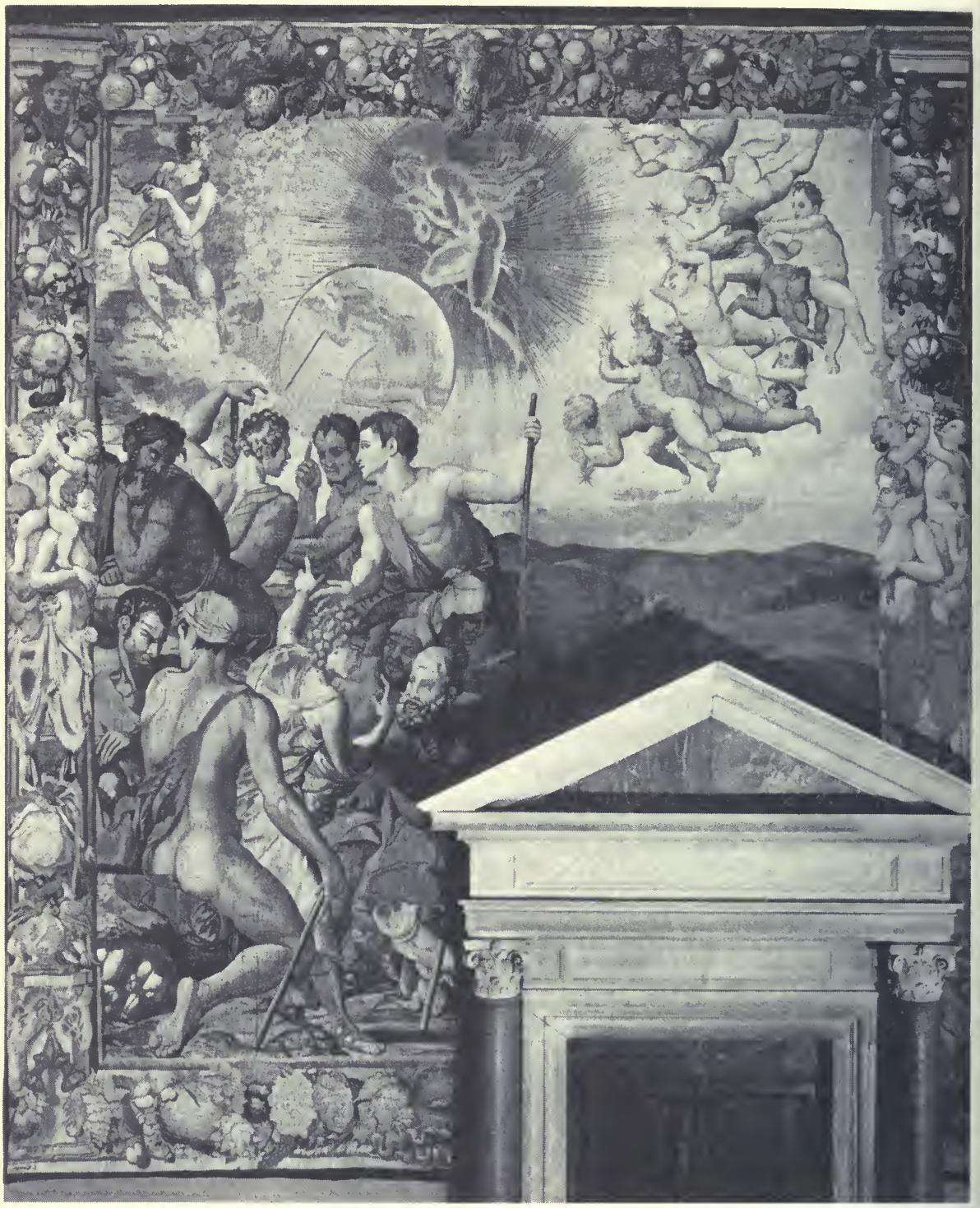

Agnolo Bronzino, Joseph Interpreting the Dream of the Sun, Moon and Stars, tapestry. Florence, Palazzo Vecchio.

rigorous moral standards in Florence. It is against this contemporary background that Bronzino's Joseph Fleeing from the Wife of Potiphar (Fig. 3) must be understood. Clearly, the tapestry illustrates Joseph's chasteness and self-control. However, it seems reasonable to assume that it also alludes to Cosimo I's continence, and perhaps was intended to reassure 


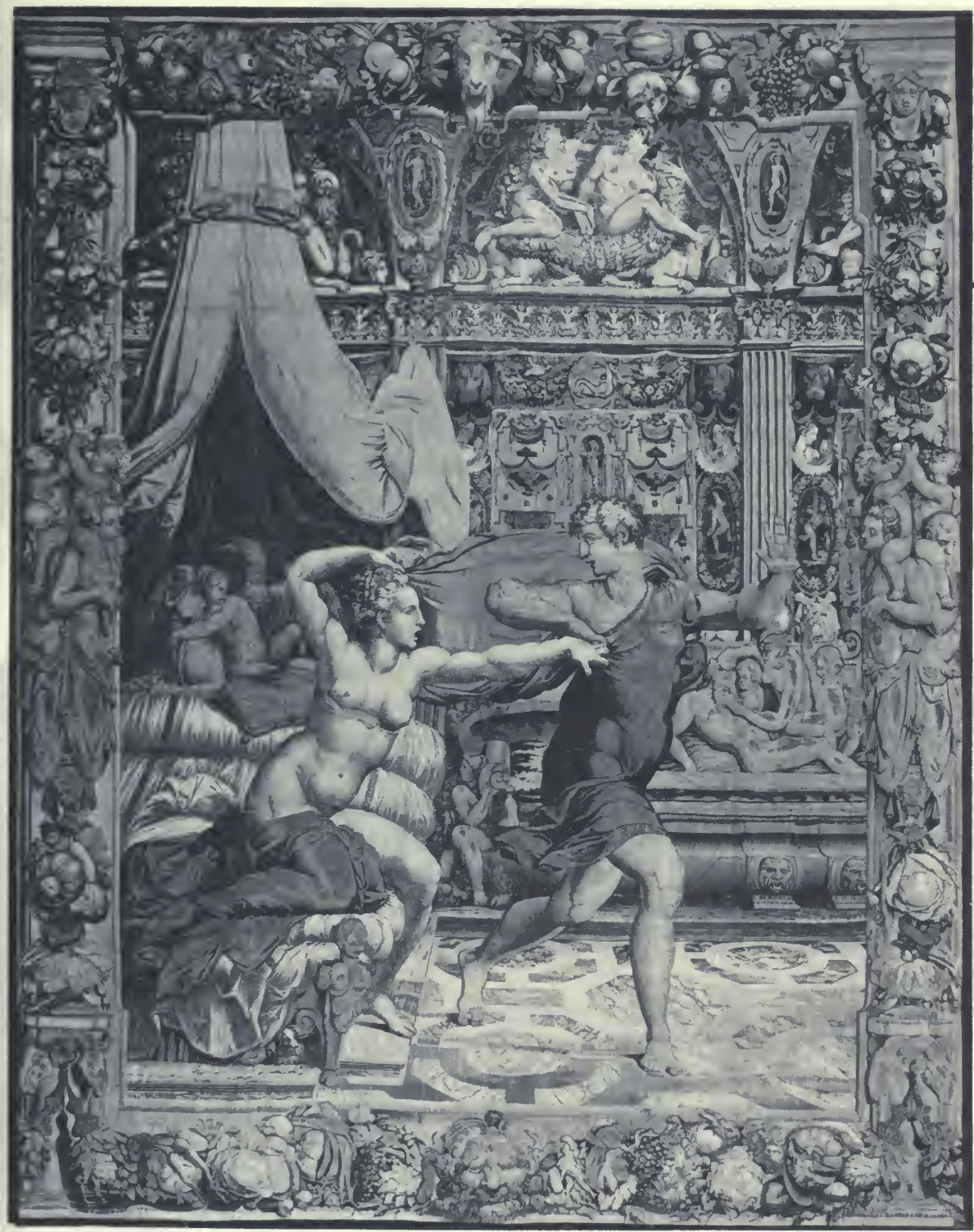

Agnolo Bronzino, Joseph Fleeing from the Wife of Potiphar, tapestry. Florence, Palazzo Vecchio.

the Florentines that Alessandro de' Medici's unbridled libertinism was a thing of the past.

According to Philo Judaeus, Joseph's readiness to forgive his brothers at once demonstrated his magnanimity and illustrated his ability as a 
statesman to "create order in disorder and concord where all was naturally discordant"' (p. 271). Throughout the period of his government of Florence, Cosimo de' Medici demonstrated a similar talent for generating order and harmony, and his contemporaries also attributed to him the virtues of clemency, equity and magnanimity. For example, in his Ritratto del vero governo del prencipe dall'esempio vivo del Gran Cosimo de' Medici, published in Venice in 1552, Lucio Paolo Rosello described clemency as one of the most important qualities of the ideal prince and one essential to his god-like nature. ${ }^{19}$ Similary, in Florence in 1578 , Baccio Baldini published a Panegirico della Clemenza in vita di Cosimo de' Medici $I .{ }^{20}$ Like Hercules, with whom he was associated for a variety of reasons, Cosimo I (Fig. 1) was seen as combining leonine strength and ferocity with magnanimity. ${ }^{21}$ In other contexts, Cosimo's clemency was seen as associating him with exemplary ancient rulers, such as Alexander or Augustus. For example, in his funerary oration in 1574 Bernardo Davanzati compared Cosimo with Alexander the Great because of their charitable treatment of their enemies; ${ }^{22}$ and in the same vein, the funerary decorations at S. Lorenzo paralleled Cosimo and Augustus on the grounds of their clemency and magnanimity towards rebels. ${ }^{23}$ In view of this widespread emphasis upon Cosimo I's magnanimity, it seems plausible to interpret the tapestry representing Joseph Pardoning his Brethren as a metaphor for Cosimo's own clemency. In fact, in this case there exists a precise Medici precedent for this kind of comparison in a medal struck for Clement VII in 1529 or 1530 by Giovanni Bernardi da Castel Bolognese. The scene on the reverse of the medal shows Joseph revealing himself to his brethren, as is made quite clear by the inscription EGO SVM IOSEPH FRATER VESTER; that Clement intended to identify himself with Joseph's clemency towards his brothers is made similarly explicit by the appearance of the Medici palle on Joseph's throne. ${ }^{24}$

In his account of Joseph's reconciliation with his family, Philo Judaeus described how each of the brothers developed a different laudatory theme, one praising Joseph's "readiness to forgive, one his family affection, [and] one his prudence" (p. 259). In fact, the virtues of prudence and family affection can be transferred to Cosimo as effectively as was the quality of magnanimity.

In the commentary on Cosimo de' Medici's impresa in Le Sententiose Imprese, Paolo Giovio has Cosimo himself identify Fate and Prudence as the principal factors governing a ruler's long-term success. ${ }^{25}$ Moreover, personifications of Prudence and Fortitude appear as the councillors of Cosimo in Vasari's painting representing Cosimo I Planning the Campaign against Siena in the Salone dei Cinquecento in the Palazzo Vecchio; and in the small Allegory of Public Happiness, which Bronzino painted for Francesco I, the figure of Prudence even has Cosimo's features as one of her faces. ${ }^{26}$ 
However, perhaps the most important characteristic associating Joseph with Cosimo I is his persistent loyalty to his family. As a result of his reconciliation with his brethren and the subsequent resettlement of his family in Egypt, Joseph became head, saviour and, in a rather precise sense, second founder of his line. In fact, the idea of Joseph as saviour and second founder of his family has a particular relevance to Cosimo de' Medici, since, especially at the beginning of his rule, Cosimo consistently presented himself as the renewer of the Medici dynasty. This idea was represented in a variety of media, but it is particularly clear in Bronzino's Portrait of Cosimo I in Armour, in the versions now in Kassel and Toledo. In these paintings Cosimo rests his helmet on a severed trunk from which emerges a leafy new branch. The amputated trunk refers to the extinction of the principal branch of the Medici family with the assassination of Alessandro, while the vigorous new branch must be identified with Cosimo I himself, heir to Cosimo il Vecchio and, literally, a new Cosimo. ${ }^{27}$

On the basis of the material presented above, it should now be evident that, for a variety of reasons, Joseph was an eminently appropriate subject for the elaborate treatment and particular emphasis that he was given in Cosimo I's tapestry cycle for the Salone dei Duecento. Not only was Joseph a model ruler and statesman, like Alexander or Augustus, but also his chastity, clemency, clear judgement and ability to provide public happiness and prosperity mirrored Cosimo's own. Moreover, like Cosimo de' Medici himself, Joseph was the second founder of his family, who guided his people to a new golden age after a period of poor government, famine and despair. ${ }^{28}$

\section{University of Michigan}

\section{Notes}

1 Quoted from C. Conti, La prima reggia di Cosimo I de' Medici nel palazzo già della Signoria di Firenze (Florence, 1893), p. 32. Cosimo's letter is dated 14 May 1540. Pier Francesco Riccio, Cosimo's majordomo, also recorded the event, but dated it a day later. (Conti, La prima reggia, p. 32: "Addi 15 Maggio 1540 in sabato a hore venti in circa vigilia dello Spirito Santo il S.re Duca Cosimo co' la S. ra Duchessa Lionora sua consorte entrò nel palazzo maggiore in Fiorenza eletto per abitazion di lor Ec.ze quod faustum foelixque sit."') Riccio's date is confirmed by an entry for 15 May in the continuation to Luca Landucci's diary. (See $A$ Florentine Diary from 1450 to 1516 by Luca Landucci continued by an anonymous writer till 1542 with notes by Iodoco del Badia, trans. A. de Rosen Jervis [London, 1927], p. 298: “15th May [the eve of the Spirito Santo]. Duke Cosimo went to live in the Palazzo de'Signori.') Research for this article was carried out with the help of a grant from the Horace H. Rackham School of Graduate Studies at the University of Michigan. Professor Charles Trinkaus read an earlier version of this study, and I am grateful to him for a number of valuable suggestions. 


\section{4 / Renaissance and Reformation}

2 The most comprehensive discussion of the Joseph tapestries to date is that by Candace Adelson in the Council of Europe catalogue, Palazzo Vecchio: committenza e collezionismo medicei (Firenze e la Toscana dei Medici nell' Europa del Cinquecento) (Florence, 1980), pp. 50-63, cat. nos. 80-99. In particular, Adelson discusses in detail the manner in which the series was displayed in the sixteenth century. According to Adelson, the tapestries were intended to hang so that they reached the floor of the Salone dei Duecento, rather than being hung some feet above floor level as is the case now. (As Adelson points out, this accounts for the presence of the painted additions in Joseph Interpreting the Dream of the Sun, Moon and Stars [Fig. 2] and the Distribution of Grain to Joseph's Brothers.) In addition, Adelson argues that the entire cycle was to be displayed at one time, and that the tapestries were to be viewed clockwise, in proper narrative sequence, beginning at the extreme left of the east wall with the Dream of the Sheaves of Corn and ending at the extreme right of the north wall with the Burial of the Bones of Joseph. (C. Conti, Ricerche storiche sull'arte degli arazzi in Firenze, Florence, 1875, p. 12, and idem, La prima reggia di Cosimo I de'Medici nel Palazzo già della Signoria di Firenze [Florence, 1893], p. 162 , had suggested that the tapestries were intended to be shown in some kind of rotation, and that only half the cycle had been displayed at one time. According to Conti, only the interior walls of the Salone dei Duecento and one of the three windows overlooking the Piazza della Signoria were to be covered with tapestries. Conti's suggestion was adopted by $\mathrm{H}$. Geisenheimer, "Gli arazzi nella Sala dei Dugento a Firenze," Bollettino d'arte, 3, 1909, pp. 137-147, who proposed an arrangement whereby the first ten tapestries were to be hung in such a way that they would have been read from left to right on the south wall and then from right to left on the east wall. Apart from its inherent awkwardness, Geisenheimer's arrangement is unsatisfactory because it assumes that the doorways now on the south wall of the room were both in existence when the tapestries were designed.) According to Adelson, the eight narrow tapestries in the series were intended for the corners of the Salone dei Duecento; two of the broader tapestries were to hang between the narrow tapestries on the east and west walls; and four of the broader tapestries were to be similarly framed on each of the north and south walls. Adelson maintains that the later tapestries in the series were designed to cover the windows on the north and east walls of the room. The arrangement proposed by Adelson has the advantage of following the correct narrative sequence while disposing the narrow tapestries in a symmetrical fashion around the room and accommodating to what appears to have been the original placement of the doorways in the Salone dei Duecento. While Adelson's reconstruction seems convincing, it is worth emphasising that normally the tapestries were stored in two wardrobes or armadi in the quardaroba segreta, and had been displayed only on special occasions. (See Conti, La prima reggia di Cosimo I, pp. 159 and 162.) Also, it seems that the tapestries were not reserved exclusively for the Salone dei Duecento. A. Lensi, Palazzo Vecchio, Milan, 1929, p. 132, quotes from a ricordo of June 1591 which informs us that the ringhiera was decorated with the Joseph tapestries for the Feast of John the Baptist. On Bronzino's drawings for the tapestries, see C.H. Smyth, Bronzino as Draughtsman: An Introduction (Locust Valley, 1971), pp. 20-41. In addition, Smyth, pp. 94-101, gives a summary of the documentation, and discusses in detail the chronology of Bronzino's first four tapestries. All sixteen of the tapestries designed by Bronzino are illustrated in E. Baccheschi, L'opera completa del Bronzino (Milan, 1973), cat. nos. 59-74; Pontormo's three tapestries are illustrated in L. Berti, L'opera completa del Pontormo (Milan, 1973), cat. nos. 130-132; that designed by Salviati is illustrated in Palazzo Vecchio: committenza e collezionismo medicei, cat. no. 87.

3 With one or two exceptions the titles given here correspond to those proposed by Adelson, Palazzo Vecchio: committenza e collezionismo medicei, cat. nos. 80-99. The principal discrepancy concerns the second of Pontormo's designs. Following Geisenheimer, "Gli arazzi," p. 145, Adelson, cat. no. 84, identifies this scene as the Temptation of Joseph. In fact, Potiphar's wife seems to point at Joseph with her right hand, as if she were identifying him or accusing him. Moreover, Smyth, in Bronzino as Draughtsman, pp. 97 and 99, entitles the tapestry the Retention of Joseph's Cloak by Potiphar's Wife and Potiphar's Wife Holding Joseph's Cloak. If this reading of the scene is correct, it would mean that this tapestry properly should come after Bronzino's Joseph Fleeing from the Wife of Potiphar, rather than preceding it, which in turn would disturb Adelson's neat arrangement of the narrow tapestries in the corners of the room. The other variations in title refer to Adelson's cat. nos. 93, 94 and 95. However, in these cases the differences are relatively minor, and do not affect Adelson's arrangement of the series. 
4 On the Borgherini series, see now A. Braham, "The Bed of Pierfrancesco Borgherini," Burlington Magazine, 121 (1979), pp. 754-765, with references to the earlier literature. Two other Renaissance prototypes for the Joseph tapestries should be mentioned here. These are Lorenzo Ghiberti's bronze panel for the Gates of Paradise and Raphael's frescoes in the Vatican Logge. Ghiberti combined five episodes from the Joseph story in a single relief - the sale of Joseph, the gathering of grain, the distribution of grain to Joseph's brothers, the discovery of Joseph's cup in the sack of Benjamin, and Joseph revealing himself to his brothers. (Illustrated in R. Krautheimer, Lorenzo Ghiberti [Princeton, 1970], pls. 98-101b.) For Leo X, another Medici, Raphael painted four Joseph scenes in the seventh bay of the Logge - Joseph Interpreting his Dreams, the Sale of Joseph, Joseph Fleeing from Potiphar's Wife, and Joseph Interpreting the Dreams of Pharaoh. (Illustrated in N. Dacos, Le Logge di Raffaello [Rome, 1977], pls. VIII, XXVIII-XXX.) However, Ghiberti's relief and Raphael's frescoes differ from the Borgherini series and from the tapestries in one very significant respect. That is, they form part of more extensive old testament cycles, rather than being independent Joseph series.

5 Illustrated fully in A. de Witt, 1 mosaici del Battistero di Firenze, 4, Le storie della Genesi e di Giuseppe (Florence, n. d.), pls. XXV-XLIX.

6 Three of my identifications of the Borgherini panels differ from those proposed by Braham, "The Bed of Pierfrancesco Borgherini." Braham, pp. 757-759 and fig. 8, identifies the third panel by Pontormo as Joseph's brothers beg for help (the Triumph of Joseph). In this case, it seems reasonable to associate the figure kneeling with bowed head, directly below Joseph's left hand, with the lines in Genesis 42:24 describing the taking of Simeon: "and [Joseph] took from them Simeon, and bound him before their eyes." The small painting by Bacchiacca, which Braham, p. 758 and fig. 11, places next in the series and identifies tentatively as Joseph orders the imprisonment of his brothers (?) may illustrate the earlier part of the same verse: "And [Joseph] turned himself about from them, and wept." Braham, p. 758 and fig. 10, entitles Bacchiacca's last panel Joseph pardons his brothers. It is not evident that this is what is represented. Rather, the painting appears to illustrate Genesis 44: 13-34, the return of-Judah and his brothers to the house of Joseph, Joseph taking Benjamin as his servant, and Judah's supplication to Joseph.

7 Adelson, Palazzo Vecchio, committenza e collezionismo medicei, p. 50, points out that the surface area of the Joseph cycle is almost twice that of Raphael's tapestry series for the Sistine Chapel.

8 There is a similar lack of emphasis upon the final act of the Joseph story in the still more extensive mosaic cycle at St. Mark's in Venice, where only three of the subjects represented by the tapestries appear in the dome and lunette devoted to Joseph's triumph. The shared scenes are the Taking of Simeon, the Distribution of Grain, and Joseph Receiving Benjamin. (Illustrated in O. Demus, Die Mosaiken von San Marco in Venedig, 1100-1300 [Baden, 1935], figs. 47 and 48.)

9 See in particular, K. Forster, "Metaphors of Rule: Political Ideology and History in the Portraits of Cosimo I de' Medici," Mitteilungen des Kunsthistorischen Institutes in Florenz, 15 (1971), pp. 65-104, and P.W. Richelson, Studies in the Personal Imagery of Cosimo I de' Medici, Duke of Florence (New York, 1978), with extensive bibliography.

10 "The Bed of Pierfrancesco Borgherini," p. 761.

11 According to J.P. Migne, Patrologiae cursus completus, Series Latina (Paris, 1844-1904), 219, col. 246: "Joseph . . . per omnes vitae suae eventus Christum Salvatorem mundi exprimebat." For a particularly elaborate paralleling of the lives of Joseph and Christ, see Hrabanus Maurus, Commentariorum in Genesim libri quatuor, Patrologiae, 117, cols. 622-644. Also see L. Réau, Iconographie de l'art chrétien (Paris, 1956), 2, i, pp. 156-157.

12 "'The Joseph Scenes on the Maximianus Throne in Ravenna," Gazette des Beaux-Arts, 6th ser., 40 (1952), pp. 27-38.

13 Philo, VI (The Loeb Classical Library), trans. F.H. Colson (Cambridge, Massachusetts and London, 1935), On Joseph.

14 MS Plut. LXIX, cod. xi. See A.M. Bandini, Catalogus codicum graecorum Bibliotechae Laurentianae, 2 (Florence, 1768), pp. 630-634, and B.L. Ullman and P.A. Stadter, The Public Library of Renaissance Florence: Niccolo Niccoli, Cosimo de' Medici and the Library of San Marco (Medioevo e umanesimo, 10) (Padua, 1972), p. 261, no. 1179. 


\section{6 / Renaissance and Reformation}

15 See L.D. Ettlinger, The Sistine Chapel before Michelangelo: Religious Imagery and Papal Primacy (Oxford, 1965), pp. 116-117.

16 Ibid., p. 116. In the Staatsbibliothek in Munich there is a notebook containing extracts made by Poliziano from a variety of authors, including Philo Judaeus. (See Mostra del Poliziano nella Biblioteca Medicea Laurenziana: manoscritti, libri rari, autografi e documenti (Florence, 1954), cat. no. 80 [Munich, Staatsbibliothek, MS lat. 748].) It appears that Ficino did not draw heavily upon Philo, but he did refer to him in his writings. Also, Philo is mentioned in the opening sentences of a manuscript vita of Ficino preserved in the Biblioteca Nazionale in Florence. (See R. Marcel, Marsile Ficin [1433-1499] (Paris, 1958), pp. 616, 620, 632, 694 and 715.)

17 I. Cheney, review of Bronzino as Draughtsman: An Introduction, by C.H. Smyth, in Master Drawings, 11, 1973, pp. 167-168.

18 Cosimo's continence was commented upon by the Welsh traveller William Thomas, who spent the winter of 1546-1547 in Florence in the household of Bartolomeo Panciatichi, whose portrait Bronzino painted. (See The History of Italy [1549] by William Thomas, ed. G.B. Parks, Folger Documents of Tudor and Stuart Civilization [Cornell University Press, 1963], p. 105: "He [Cosimo] hath divers fair children by his wife and loveth her so well that in manner he never goeth abroad [unless it be to church] without her and is reputed to be a very chaste man.")

19 See Forster, "Metaphors of Rule," p. 98.

20 See Richelson, Studies in the Personal Imagery of Cosimo I, pp. 42-43, and n. 73 on p. 74.

21 Forster, "Metaphors of Rule," p. 79, and Richelson, Studies in the Personal Imagery of Cosimo $I$, p. 86, and n. 24 on p. 100. Also see L.D. Ettlinger, "Hercules Florentinus," Mitteilungen des Kunsthistorischen Institutes in Florenz, 16 (1972), pp. 119-142, and H. Utz, "The Labors of Hercules and Other Works by Vincenzo de' Rossi," Art Bulletin, 53 (1971), pp. 342-366.

22 Richelson, Studies in the Personal Imagery of Cosimo I, n. 55 on p. 68.

23 Forster, "Metaphors of Rule," p. 86.

24 On this medal, see P. Bonanni, Numismata Pontificum Romanorum, I, Rome, 1699, pp. 189-191, VIII, and, more recently, The Age of Vasari (Notre Dame, Indiana: University of Notre Dame, 1970), cat. no. M7 on p. 191, with an illustration on p. 197, and N.T. Whitman, Roma Resurgens: Papal Medals from the Age of the Baroque (Handbook to the Exhibition) (Ann Arbor, Michigan: The University of Michigan Museum of Art, 1981), cat. no. 2, p. 7. Whitman suggests that the medal was intended as a promise of papal clemency to Florence after the reestablishment of Medici rule in the city.

25 See Forster, “Metaphors of Rule," fig. 28 on p. 90.

26 For an illustration of Vasari's painting, see P. Barocchi, Vasari Pittore, 1964, fig. 79. For a recent discussion of the iconography of Bronzino's painting, see Palazzo Vecchio: committenza e collezionismo medicei, cat. no. 517, p. 274, Allegoria della Felicità. For a good colour illustration of the picture, see C. McCorquodale, Bronzino (New York, 1981), pl. XVI. I am presently preparing a detailed study of the iconography of the painting.

27 On the Portrait of Cosimo I in Armour, see G. Smith, "Bronzino's Portrait of Stefano Colonna: A Note on its Florentine Provenance," Zeitschrift für Kunstgeschichte, 40 (1977), pp. 268-269, n. 18 , with additional references.

28 The themes of the statesman and second founder are also emphasized in the two other major decorative cycles commissioned by Cosimo I in the Palazzo Vecchio in the forties - Bronzino's Chapel for Eleonora, in which the principal character is Moses, and Salviati's Sala dell'Udienza, in which the hero is Marcus Furius Camillus. Associated by Machiavelli as severe but just rulers (Discorsi sopra la prima deca di Tito Livio, Book III, chapter XXX), Moses and Camillus, like Joseph, were considered model leaders and legislators. Beyond this, however, both were second founders, the former in leading the Israelites from Egypt to the promised land, and the latter as the saviour of Rome from the Etruscans and Gauls. For further information on Camillus, see Forster, "Metaphors of Rule," pp. 73-74. On Moses, see Richelson, Studies in the Personal Imagery of Cosimo I, pp. 109-111. For other suggestions linking the Joseph, Moses and Camillus cycles, see Cheney, review of Bronzino as Draughtsman, pp. 167-168. 